\title{
ENVIRONMENTAL POLICY IN THE EUROPEAN UNION AND THE CONTESTED NOTION OF SUSTAINABLE DEVELOPMENT
}

\author{
James Connelly*
}

\begin{abstract}
This article considers the history of sustainable development in the EU together with some of the difficulties in formulating a coherent conception of sustainable development. This is supplemented by a theoretical discussion of the nature of concepts and their definition. Following an examination of sustainable development conceived as ecological modernisation and as a story-line capable of sustaining a politically successful discourse coalition, it concludes by asking whether the concept of sustainable development should be abandoned or, at least, radically reconceived.
\end{abstract}

Keywords: economic growth, environmental action programs, ecological modernisation, Lisbon strategy.

\section{AVRUPA BIRLIĞİ'NDE ÇEVRE POLITTIKASI VE TARTIŞMALI SÜRDÜRÜLEBILIR KALKINMA MEFHUMU}

\section{$\ddot{O}_{z e t}$}

Bu makale Avrupa Birliği'nde sürdürülebilir kalkınmanın tarihçesini, sürdürülebilir kalkınmanın tutarlı bir şekilde kavramsallaşmasindaki zorluklarla birlikte incelemektedir. Çalışmadaki bu yaklaşım da kavramların doğası ve tanımlarındaki teorik tartışma ile desteklenmektedir. Dolayısıyla bu makalede, öncelikle sürdürülebilir kalkınmanın hem ekolojik modernleşme olarak ve hem de siyaseten başarll bir söylem koalisyonu sürdürmeye muktedir bir olaylar dizisi olarak kavranması irdelenecek ve akabinde de sürdürülebilir kalkınmanın tamamen bir kenara mı bırakılması mi ya da en azından radikal bir şekilde yeniden kavramsallaştırılması gerektiği sorusuna yanıt aranacaktır.

\footnotetext{
* Prof Dr., University of Hull, Department of Politics and International Studies, e-mail: j.connelly@ hull.ac.uk
} 
Anahtar Kelimeler: Ekonomik büyüme, çevre eylem programlarl, ekolojik modernleşme, Lizbon stratejisi.

\section{Introduction}

In 1988, in a Declaration on the Environment, the EC heads of government stated that "sustainable development must be one of the over-riding objectives of all Community policies" (European Council, 1988: 8). However at the Rome Summit two years later the term 'sustainable development' was replaced by a commitment to environmental protection to ensure 'sustainable growth', a formulation later also used in the Maastricht Treaty and still current. Whatever the precise meaning of the phrase, this seems reasonably straightforward; but for Susan Baker, it is precisely here that the problems start:

The Treaty, however, also speaks about promoting economic and social progress which is sustainable. To complicate the matter further, the Treaty's section dealing with developmental cooperation requires Union policy to foster 'the sustainable economic and social development of the developing countries' - which at first sight appears to mean the Union applies the concept of sustainable development to the developing countries while applying 'sustainable growth' to the Union (Baker, 1997: 92).

This leaves a rather confusing situation, in which the Maastricht Treaty speaks simultaneously of 'sustainable progress', 'sustainable growth' and 'sustainable development'. How was this position reached and has it improved? The short answer is that politically it was arrived at through fusing the results of two inter governmental conferences, one on European Monetary and Political Union (EMU) and the other dealing with the rest of the treaty. Germany pressed for sustainable development as against the southern members whose interests lay elsewhere.

This paper traces these deliberations and fusions conceptually rather than historically and argues that what emerged is - depending on one's view - either sustainable development as a political fudge or sustainable development as ecological modernisation. Of course, much turns on how the interpretation of the concept of sustainable development and how it is deployed. Agreement on the importance of the concept of sustainable development can be found across the ideological spectrum. Groups as diverse as neo-liberal free-marketers and radical bio-regionalists agree on its importance but not about its implications and therefore not on its application. Consensus on the importance of the concept of sustainable development disguise the extent of the divergence in the way it is understood and interpreted by different people and interests. Sometimes it seems that all that these different groups have in common is not the concept, but merely the phrase. The overall purpose of the paper is to suggest that the EU's adherence to sustainable development is fraught with problems and tensions inherent from the outset and 
never seriously addressed. Further, these difficulties matter and have real consequences. Real problems (whether conceptual or empirical) cannot be papered over by fine phrases, no matter how elegantly and carefully phrased.

\section{The Concept of Sustainable Development}

Although the concept of sustainable development is contested and contestable, contemporary debates were nonetheless dominated by a particular interpretation, that is, ecological modernisation and its successors. This is the interpretation in which economic growth, the development of technology and environmental protection are not regarded as competitors but as co-beneficiaries. Ecological modernisation adopts a distinctive stance on the question of economy-environment integration, challenging the assumption that there is a zero-sum trade-off between economic prosperity and environmental concern. It could, it was claimed, offer a 'win-win' scenario whereby economic growth and environmental protection could be reconciled. As Maarten Hajer states: "ecological modernisation can be defined as the discourse that recognises the structural character of the environmental problematique but none the less assumes that existing political, economic, and social institutions can internalise care for the environment" (Hajer, 1995: 25).

Sustainable development was defined by the Brundtland Report in 1987 as "development that meets the needs of the present without compromising the ability of future generations to meet their own needs" (WCED, 1987: 8). It is seen as development based on consumption and production patterns that do not degrade natural resources, that protect the environment, promote equitable sharing of well being to all and alleviate poverty. The Report emphasises the mutual reinforcing of economic growth, social development and environmental protection. As with The Limits to Growth (Meadows et al, 1972), environmental degradation is linked with patterns of economic development. However, by contrast with the Club of Rome's view, which characterised the relation between economic growth and environmental protection as a zero sum game, Brundtland concluded that (on the contrary) continued economic growth was an essential prerequisite for environmental protection. This interpretation of sustainable development has been widely endorsed: indeed, it is easy to understand why such a definition of sustainable development could be supported by many different parties (including governments, businesses, reform-minded environmentalists and scientists) in that it neatly squares the circle by offering both economic growth and environmental protection. Rather, then than either endorse or reject the darker green view that fundamental reorganisation of the major institutions of modern society was a necessary precondition of long term sustainability, a consensus crystallised around the discourse of ecological modernisation. This led to heightened optimism about the ability of policy makers, and business to integrate ecological concerns into the presumed market economic framework. In such a framework the search for new 
environmental policy instruments, such as emissions trading schemes and the general use of economic instruments, was both desired and rewarded.

\section{Sustainability Goals and Strategies}

The obvious place to locate the broad direction of EU goals and strategies on sustainability is the periodically issued environmental action programmes. These show both the EU's level of commitment to and understanding of the concept. For example, sustainable development is identified as the main objective of environmental policy in the very title of the Fifth Environmental Action Programme (5EAP), Towards Sustainability - A Community programme of policy and action in relation to the environment and sustainable development. This objective requires "a policy and strategy for continued economic and social development without detriment to the environment and the natural resources on the quality of which continued human activity and further development depend" (COM, 1992: 18). The Sixth Environmental Action Programme (6EAP), 2002-2012 builds on this objective (COM, 2001a).

The 5EAP was adopted only a few months before the Rio Earth Summit in 1992; moreover, it was prepared in parallel with the main Rio agreements so that it shares most of their strategic objectives and principles. Whereas previous programmes tended to be lists of proposed legislation, the focus of the 5EAP was anticipatory and committed to long term sustainability. It also signalled a move away from a traditional command and control approach. In addition to a more explicit recognition of the concept of subsidiarity, there is a move towards deregulation and market-based policies (economic incentives, taxation, and voluntary agreements). Further, an emergent theme was integration of the environment into the development and implementation of other policies as a fundamental prerequisite for achieving sustainable development. The 'Cardiff approach' required that all technical councils report on the integration of environmental concerns into all sectoral policies. The 5EAP attempted to address the fundamental causes of environmental degradation as a means of creating a more sustainable economy and society: it states that the principle of sustainable development should be incorporated into all other EU policies. However, its approach to sustainability is redolent of Brundtland in that the rhetoric of ecological modernisation and weak sustainability is dominant and that it focuses on breaking the perception of a tradeoff between environmental protection and economic development.

Thus, although the 5EAP contains the EU's most explicit commitment to sustainable development, it is a commitment to a weak rather than a strong conception. Why did the EU adopted such a weak view? The short answer is: because of the context within which its environmental policies evolved and the 
extent to which EU policy making is generally incremental in character. Policy proposals that fit with the strategy of environmental 'quality management' stand a greater chance than more radical policies. As Susan Baker notes, "the concept of sustainable development has been interpreted by the Union (and its member-states) to fit within the confines of managerial as opposed to radical policy solutions" (Baker, 1997: 102; see also Baker, 2007).

However, even if the dominant understanding of sustainable development is ecological modernisation, this is progress given that the EEC originally made absolutely no reference to environmental concerns. The point is that even though it clearly does not go far enough for many greens, it is worth considering whether it might provide a critical standpoint from which to judge the continuing development of EU environmental policy. For example, the principles and policies enunciated by the 5EAP could be deployed to combat the tendency for member states to interpret the subsidiarity principle negatively and to begin a move toward integration of environmental policy across policy sectors.

The Sixth Environmental Action Plan (6EAP) is intended to go further than its predecessors by adopting a more strategic approach. However, it is also more general than its predecessor and strikingly devoid of particular goals. A prominent theme running is working with business and consumers to achieve greener forms of production and consumption. One striking feature is that it embraces the ideals of ecological modernisation. A central goal is the de-coupling of economic growth from environmental damage: "to ensure the consumption of renewable and nonrenewable resources does not exceed the carrying capacity of the environment. To achieve a de-coupling of resource use from economic growth through significantly improved resource efficiency, dematerialisation of the economy, and waste prevention" (COM, 2001a, Executive Summary).

Like its predecessor, the 6EAP is also committed to extending the range of policy instruments employed and frequently speaks of promoting, encouraging and supporting action by business. In this ambition the EU is firmly in line with important developments in environmental policy. However, commentators have argued that the 6EAP tends to be stronger on rhetoric than on substance. They suggest that it is thin on specific commitments and timetables for achieving its environmental objectives, and that those objectives are themselves expressed in extremely general terms. This is inevitable given the fragile conception of sustainable development at its heart. It might be argued, of course, that substance is left to the thematic strategies, but we should not overlook the importance of the action programmes in reflecting and/or establishing the language and conceptual framework of environmental policy. 
Sustainable development has been a fundamental objective of the European Union since 1997. It was enshrined as Article 2 of the Treaty. It is supposed to underpin all EU policies and actions as an over-arching principle. As a complement to the broad EU strategy for socio-economic reforms (the 'Lisbon agenda'), the EU adopted an equally ambitious Strategy for Sustainable Development (SDS) at the Gothenburg Summit a year later in 2003 where the Swedish Presidency initiated the inclusion of environmental concerns within the Lisbon Strategy. Right at the start it refers to the new Lisbon strategic goal "to become the most competitive and dynamic knowledge-based economy in the world capable of sustainable economic growth with more and better jobs and greater social cohesion" (COM 2001b: 2). It follows this with the statement that:

Decoupling environmental degradation and resource consumption from economic and social development requires a major reorientation of public and private investment towards new, environmentally-friendly technologies. The sustainable development strategy should be a catalyst for policy-makers and public opinion in the coming years and become a driving force for institutional reform, and for changes in corporate and consumer behaviour. Clear, stable, long-term objective will shape expectations and create the conditions in which businesses have the confidence to invest in innovative solutions, and to create new, high-quality jobs. (Ibid: 2-3)

A few pages later we find the statements that "policies must have sustainable development as their core concern" (ibid: 6) and:

our combined long-term prosperity depends critically on advances in knowledge and technological progress. Without these investments, adjustment to sustainable development will have to happen much more through changes in our consumption patterns. By promoting innovation, new technologies may be developed that use fewer natural resources, reduce pollution or risks to health and safety, and are cheaper than their predecessors (ibid: 7).

It also refers to the principle of decoupling: the objective being to "break the links between economic growth, the use of resources and the generation of waste" (ibid: 12). Overall, the EU strategy for sustainable development 'asserts that economic growth is not an end in itself and sustainable development is the key to achieving "balanced and responsible progress in social, economic, and environmental spheres" (İzci, 2005: 87).

In June 2005, the Brussels European Council adopted a declaration on 'guiding principles for sustainable development', which stated explicitly that the "renewed Lisbon agenda is an essential component of the over-arching objective of sustainable development" (COM 2005b: 2). Later in the year the Commission started a review of the Sustainable Development Strategy adopted 
during the 2001 Gothenburg European Council. The 2005 Review of sustainable development strategy (COM 2005a) states that the EU treaty commits it "to work for the sustainable development of Europe based on balanced economic growth and price stability, a highly competitive social market economy, aiming at full employment and social progress, and a high level of protection and improvement of the quality of the environment." It follows this up with the claim that Lisbon and the Sustainable Development Strategy are mutually reinforcing and target complementary actions (ibid: 4). The German Environmental Experts Council (SRU), was highly sceptical of this claim, arguing that the EU has no clear strategy. Given the obviously uneasy and unresolved issue of the relation between the Lisbon Strategy, the 6EAP and the Sustainable Development Strategy, they clearly have a point. It states that the commission is "firmly committed to sustainable development" and that "we need growth and more jobs, a cleaner and healthier environment" and that "our future prosperity and quality of life will depend on our capacity and commitment to change our production and consumption patterns and to decouple economic growth from environmental degradation" (ibid: 6). It continues by stating that the strategy has the following components:

It sets out a broad vision of what is sustainable. The strategy's basic message is that, ultimately, the economic, social and environmental dimensions of sustainability must go hand-in-hand and mutually reinforced one another: "sustainable development offers the European union a positive long-term vision of a society that is more prosperous and just, and which promises a cleaner, safer, healthier environment - a society which delivers a better quality of life for us, for our children, and for our grandchildren." Understanding the importance of and the interrelationships between these three pillars of sustainable development is crucial (ibid: 7-8).

Later there is a commitment to "making sure that market prices reflect the true costs of economic activities to society" (ibid: 11); there is discussion of transport (ibid: 16) - but nothing on air travel. And there is comment on the three dimensional nature of sustainable development - "which can only be achieved if economic growth, social inclusion and environmental protection go hand in hand" (ibid: 19).

On the Review of the Sustainable Development Strategy: A Platform for Action (COM 2005d) states that "the principles and objectives of sustainable development - economic prosperity, social equity, environmental protection and international responsibilities" were reaffirmed by the European council (ibid: 3). It states unequivocally that "sustainable development is the overarching long term goal of the European Union set out in the Treaty" (ibid: 4) and that "on the economic side, the renewed Lisbon strategy is the motor for growth and jobs ... A stronger European economy is vital to and part of sustainable development; it will help generate the means to invest, for example in a cleaner environment, in better 
education and health care and in social protection. In turn, more sustainable use of natural resources and increased social justice are critical to our economic success" (ibid: 4 ).

Although the EU claims that sustainable development is an over-arching principle, the issue of Europe's economic competitiveness in the face of globalization, and, latterly, global financial crisis and the difficulties facing the Eurozone, have come to dominate the political agenda. The three pillars of the Lisbon strategy (economic competitiveness, social inclusion and environmental protection) were compared (by Barroso) to "three children", one of which competitiveness - needs more attention than the others. Several commissioners have stated that economic growth must come first before the EU can act to protect the environment or implement social protection policies. The fact that the EU has a competitiveness council but no sustainable development council indicates that sustainable development is not yet a real political concern.

This view is not necessarily contradicted by reassurances such as Barroso's that "the Sustainable Development Strategy and the Lisbon Strategy are mutually reinforcing" (Euractiv, 2005). Again, The Citizen's Agenda (2006) contained far more on jobs and growth than on sustainable development. Europe 2020, maintains an impressive (and genuine) set of targets for sustainable growth which include reducing greenhouse gas emissions by $20 \%$ compared to 1990 levels by 2020 (with the proviso that EU will go further and reduce by $30 \%$ if other developed countries make similar commitments and developing countries contribute appropriately). However, the problem is precisely that it identifies these as the primary targets for sustainable growth, which is both reductive (because it reduces the notion of sustainability to a very narrow range of features) and uncritical (because it does not address the assumption that the notion of sustainable growth is, to say the least, a tricky concept which upon analysis might be rather more fragile than they assume). Indeed, the hijacking of logic by rhetoric is apparent in the juxtaposition of sustainable growth with smart growth and inclusive growth: all desirable goals, no doubt, but what is their substance? The document asks "How will the EU boost sustainable growth?" and answers that it will do so through two "flagship initiatives". The first is that of a "resource efficient Europe", which to its credit states that "to support the shift towards a resource-efficient, low-carbon economy, our economic growth must be decoupled from resource and energy use by reducing $\mathrm{CO}_{2}$ emissions, promoting greater energy security and reducing the resource intensity of what we use and consume" (Europe 2020). This goes together with 'an industrial policy for the globalisation era'. This means that EU will develop "an industrial policy that will support businesses - especially small businesses - as they respond to globalisation, the economic crisis and the shift to a low-carbon economy, by supporting entrepreneurship - to make European business fitter and more 
competitive, covering every part of the increasingly international value chain from access to raw materials to after-sales service" (ibid). This is assumed to be compatible with the first means: but the compatibility is assumed whereas it needs to be proved.

EU environmental policy always has been based on a notion of weak sustainable development. This is not surprising given the EU's origins as a community dedicated to promoting economic growth and prosperity. Indeed, environmental policy was initially driven by the harmonisation of national environmental laws in order to avoid barriers to trade in establishing the Single European Market: this perhaps indicates the limit to which environmental policy can escape from or challenge the EU's primary economic rationale. The issue to consider is whether and to what extent the EU's adoption of sustainable development as a policy target (whatever their own interpretation of the term) provides a criterion against which its success or failure can be judged in the future. Let us turn, then to a brief consideration of the concept of sustainable development itself.

\section{The Problem with Sustainable Development}

Wilfred Beckerman is well known as a critic of the concept of sustainable development. He points out that "sustainable development is claimed to provide a wider concept of what development should consist of than do conventional measures of economic growth" (Beckerman, 2001: 71). He argues that "the concept of sustainable development has simply become more confused as time goes by and bears little or no clear relationship to any of the statistical 'indicators' of sustainable development that, from time to time, are bandied about. Indeed ... It would be difficult to find another field of research endeavour in the social sciences that has displayed such intellectual regress" (ibid: 72-3). However, despite its intellectual fragility, sustainable development "is now firmly entrenched in the minds of many institutions, individuals, and policy-makers. Apparently, some large corporations are now so concerned with the political correctness of sustainable development that they have incorporated programs into their computers that automatically insert the word 'sustainable' before the word 'development' in any document they produce" (ibid: 73). One might ask whether the EU has such a program.

For Beckerman sustainability is either strong or weak. In his view strong sustainability (in which there is little or no substitution between natural and human capital) is distinctive and makes sense, but is ethically dubious and nonoperationalisable. Weak sustainability, on the other hand, (which allows substitution between natural and social capital) makes sense and is operationalisable: but suffers from the defect that it adds nothing to standard welfare economics. 
From the opposite direction, Dick Richardson argues very strongly against the current concept of sustainable development:

Sustainable development is a political fudge: a convenient form of words, promoted, though not invented, by the Brundtland Commission, which is sufficiently vague to allow conflicting parties, factions and interests to adhere to it without losing credibility. It is an expression of political correctness which seeks to bridge the unbridgeable divide between the anthropocentric and biocentric approaches to politics. Beneath the rhetoric of the political platform, the reality is that the concept of sustainable development as presently used is inherently contradictory and begs a number of important questions (Richardson, 1997: 43)

Richardson argues that for the concept to have any real meaning, "other than as a consensual phrase of political agreement", it needs to be radically redefined along purely ecological lines and that if that is not possible it should be abandoned (ibid: 43). In policy terms he thus broadly agrees with Beckerman, although for very different reasons.

For Richardson, the Brundtland definition was a compromise: "It was a "catchall" definition which left all the commissioners happy: a good political fudge - and an excellent political slogan - but on deeper analysis a vague, contradictory, even meaningless concept" (ibid: 46). He suggests that the key to understanding the Brundtland approach is that "it frames anthropocentric programmes and the industrial worldview in the language of biocentricity". Rhetorically it unites the supporters of industrial production with those who would mitigate its effects on the environment. This is because:

The Brundland phraseology unites the advocates of exponential growth with the exponents of weak sustainable development and strong sustainable development. In essence, the supporters of Brundtland do not seek to question the concept of quantitative growth measured in traditional terms, although adherents of strong sustainable development may wish to see it redirected in part along qualitative lines. In contrast, the advocates of a biocentric approach question the very concept of quantitative growth. (ibid: 47)

The problem with the Brundtland commission was that it tried to "unite the ununitable", that is, the anthropocentric and biocentric approaches to the natural world, by means of an agreed form of words. For Richardson it was an act of political consensus which sought to "bring together not only governments (both left and right), but the business community, the scientific establishment, nongovernmental organizations and even environmentalists" (ibid: 47). Clearly, as it is almost universally subscribed to, it achieved considerable success, but at a huge price: 
By the very fact that it based its findings on the need for political consensus, the Brundtland Commission begged the very questions that it was established to analyse. What, in fact, constitutes development? What is the relationship, if any, between, development and growth? How can needs be identified? How should future needs be compared with present needs? What are needs as distinct from desires? Which future generations should be taken into account in formulating policy? The next generation? The next but one? Or, given the problem of nuclear waste, the next but twenty-one? (ibid: 47-8).

His conclusion is that if the concept is to have any utility (other than as a political slogan) it needs to be radically redefined, and its implicit (but unacknowledged) reliance on anthropocentrism acknowledged and removed. He argues that the Brundtland commission produced a formula, "which by the manipulation of terminology endeavoured to obscure the contradiction between the anthropocentric and biocentric approaches to sustainability.' However, beneath the rhetoric, the Brundtland concept of sustainability is "totally anthropocentric in character" (ibid: 52).

For Richardson this is upside down because, for biocentrists, "the central problem is not the incorporation of the environment into economic policy, but the incorporation of economic policy into sustaining the biosphere" (ibid: 57). Rather than accommodating the environment to growth, growth must accommodate itself to the environment. Richardson then considers whether, given the intrinsic difference between the anthropocentric and biocentric approaches, there might be a better term to express the biocentric viewpoint. One possibility he canvasses in that of 'sustainable sufficiency.'

Beckerman and Richardson from their opposed vantage points make a formidable case for the view that our current conception of sustainable sustainability is both flawed and contradictory and in need of replacement either by a consistent biocentric or human welfare view. It might be argued that there are two consequences: first, that we have to recognize the contradiction and choose; secondly to decide which direction to choose. But it appears that the thinking of the EU has not developed beyond Brundtland and continues to display a marked blindness to the existence of the dilemma, never mind to the difficulty of choosing which horn of the dilemma to embrace. We might conclude at this point that, given the conceptual incoherence identified, the concept of sustainability at the heart of the EU's environmental policy will inevitably bifurcate leaving a shipwreck rather than an environmental lifeboat. However, perhaps this is all too hasty. Complex concepts are not disposed of so easily, either in theory or in practice. Let us therefore consider this matter further, both conceptually and pragmatically. 


\section{Conceptualizing and Defining Sustainable Development}

Definition of political, social or economic concepts is no easy matter. Although Sartori claims that "there is, ultimately, only one kind of definition, the stipulative" and argues that the development of a science requires "the formulation of a special and specialised language", and that "the various sciences ... took off by inventing neologisms, by reducing by definition the ambiguity of their key terms, and by consistently abiding by syntactical rules" (Sartori, 1987: 260). However, it is precisely this claim that we ought to examine, just as we should also examine the parallel claim that all definitions are ostensive -of course, some definitions are clearly stipulative and others ostensive, but not all meaning can be derived from this sort of definition. This is because such definitions presuppose the existence of language and for that reason they cannot account for language itself. Technical terms can be defined and other terms cannot. Only if sustainable development (or sustainability) is a technical term in this sense can it be defined in the way that Sartori requires. When Nietzsche remarked that "all concepts in which an entire process is semiotically concentrated elude definition; only that which has no history is definable" (Nietzsche, 1968: 517) this is what he had in mind. The point is simply that if sustainability were the sort of thing which could be defined stipulatively then we could reasonably expect and demand such a definition. However, before considering the political demands made of the concept, and the political advantage of leaving it vague and amorphous, we should consider whether the impossibility of easy definition arises from the fact that it is an internally complex and valued laden concept. Let us examine this a little further.

R.G. Collingwood showed that with concepts of a particular sort, there will never be (and in principle cannot be) sharp and clearly delineated boundaries (2005 [1933]). Later W.B. Gallie similarly identified certain concepts - which he termed 'essentially contested' - as intrinsically difficult to pin down and define. Such concepts overlap in extension and intension, and there can be no definition short of conceptualization of the whole activity in which they are employed (and of which they are constitutive) and each term employed in the analysis is itself contestable (Gallie, 1964). William Connolly suggests that concepts of this sort are cluster concepts, which are "internally complex ... with a broad and variable set of criteria where each criterion is itself relatively complex and open" (Connolly, 1983: 14).

The problem with sustainable development is that it needs to be operationalised and implemented; and yet it is not clear whether this can be done in a meaningful way. However, let us note that it does not follow from the fact that a concept is essentially contestable that it cannot be used in theory or in practice. The issue is whether it has sufficient clarity for the purposes for which it will be used. But if a concept is essentially contestable and also suffers from implicit internal contradictions, trouble is inevitable when those contradictions become explicit. 
Sustainable development is an essentially contestable concept, partly because of its irreducible complexity and its irreducible normativity. It is therefore not amenable to stipulative or ostensive definition.

Although it might be reasonably argued that the term sustainable development (like democracy) can be meaningfully employed in the absence of complete agreement, there is a complication. Democracy and sustainable development are both essentially contestable, but they differ in an important way: the latter is intrinsically future directed in a way that the former is not. It is necessarily future directed because it is a transitional concept. And it is future directed in a way which makes it very hard indeed to say whether in the present we have grasped it or not. The problem is not only that it is future directed, but there is no final 'success point', rather merely the hoped for achievement of a process adequate to our aspirations. By contrast, consider choosing a holiday, which is both an empirical and a normative activity. We have to know not only the available choices but also to recognize that there is no perfect holiday because there will be competing and conflicting expectations and hopes. But at least with a holiday we can plan; we can see it as something we project into the future but can also see beyond. Part of our planning for a holiday, indeed, consists in the means we take to ensure we remember the holiday. That is why we pack a camera: and at some point we can judge the holiday good or bad. We might even later in life go back and do all the things we missed the first time.

For sustainable development none of this holds. There will be no point at which we can look back. We can form interim judgements at various points, but that is all. And even if we have done well so far, we have to judge our present actions in terms of a future that will never arrive. Obviously, if we get it completely wrong we might come to know that; but knowing that we have it right is a different matter; it is hard even to say that we have attained an asymptotic approximation to the ideal as we have no end point against which we can judge our actions. Perhaps all we are left with is a variant of Popper's point that we cannot know the truth with certainty, but only the false, and that therefore the best we can hope to say is that we haven't yet obviously got it wrong.

That is one problem with sustainability as a transitional concept. Let us now consider another aspect of the essentially contestable of sustainable development: the definition of needs. Even assuming that needs can be fixed with sufficient precision and distinguished carefully from wants, it does not follow that they can all be satisfied, and if they cannot the Brundtland conception breaks down, for we might not be able to meet the needs of the present at all, never mind leaving enough for posterity. It is not, of course, certain that we cannot meet the needs of those in the present, but whether we can or not is partly an empirical and partly a conceptual matter complicated by the intractability of the concept of needs. 


\section{Sustainable Development as Ecological Modernisation}

The dominant conception of sustainable development in the EU has for a long time been ecological modernisation, which is an attempt to increase the environmental efficiency of the economy by (for example) moving away from energy and resource intensive industries and 'end of pipe' solutions to clean techniques and technologies. Its advocates argue that these changes have the potential to make significant improvements in the environmental performance of industrial economies. It is presented as a means by which capitalism can accommodate the challenge of environmentalism and seen not as a threat to capitalism but as the introduction of a new phase of capitalist development. Ecological modernisation thus offers governments a policy approach which allows them to reconcile previously antagonistic environmental and business interests. Its advocates argue that a number of advanced capitalist nations are already developing along these lines and that we are witnessing a 'decoupling' of economic growth from ecological damage.

Susan Baker argues that the EU's conception of sustainable development is largely symbolic and that it has really made a declaratory commitment to sustainable developments and then adopted a strategy of ecological modernisation (Baker, 2007: 313). She claims that the EU has not only firmly adopted ecological modernisation but also promoted its identification with sustainable development as it has promoted it principles:

The strategy of ecological modernisation makes environmental management compatible with the raison d'etre of the EU integration project. It is in keeping with its key tenet, namely the construction of a neo-liberal, free market economy in support of industrial competitiveness. With its substantial supranational authority over environment policy, the EU has played a role in promoting ecological modernisation, and in the diffusion of its principles, particularly to leader environmental states, and into the industrial sector. While the literature often confuses ecological modernisation with sustainable development, ecological modernisation is a more limiting concept. It does not address the underlying contradiction in capitalism: a logic of ever-increasing consumption in a world characterised by material resource limitations. (Baker, 2007: 313).

Let us develop some of these themes, in particular the deficiencies in the concept of ecological modernisation and therefore the weakness of identifying it with sustainable development in general. A number of important criticisms have been made of ecological modernisation: for instance, the decoupling thesis has been challenged, as has its perceived neglect of issues of social justice, its conceptualisation of nature, and its faith in technological and scientific progress. 
First, the decoupling thesis has been challenged because many apparent examples of decoupling have only been achieved through a displacement of high energy consuming and polluting industries to less industrialised countries: in other words, environmental damage has been exported. Further, increased efficiency of resource use makes no practical difference if consumption of goods increases and the economy continues to grow. There might be decoupling per unit of GNP, but if GNP is still increasing the progress is only relative: there is no evidence for absolute decoupling. Secondly, critics argue that ecological modernisation has failed to address pressing issues of social justice on two fronts: within industrialised nations and between highly industrialised and Third World nations. It is argued that ecological modernisation theory is silent on questions of the distribution of environmental goods and bads, focusing primarily on the overall domestic environmental impact of national economies in the industrialised part of the world. Environmental justice campaigners within industrialised nations highlight the unequal distribution of environmental risks; for example, the siting of toxic waste disposal facilities close to lower socio-economic neighbourhoods. Thirdly, ecological modernisation fails to engage with the serious environmental moral critique. Admittedly nature is integrated in decision making processes, particularly economic policy, and is no longer viewed as a free good. However the view of nature is still a highly instrumental one because the discourse is that of ecoefficiency in which a reorientation towards the natural world is promoted for reasons of efficiency and not ethics. This is seen in the promotion of policy techniques such as extended cost-benefit analysis and cost-effectiveness approaches in which environmental impacts are internalised, but only in economic terms. Although there may be pragmatic arguments for this internalisation, it misrepresents the different types of value we associate with the nonhuman world and reinforces a technocentric worldview. Finally, there is a widespread suspicion that ecological modernisation is simply a strategy of political accommodation, in other words, "a rhetorical ploy that tries to reconcile the irreconcilable (environment and development) only to take the wind out of the sails of 'real' environmentalists" (Hajer, 1995: 33).

Hajer analyses the way political ideas are used to construct story-line, narrative and examines the discourse coalitions they make possible. In this sense, the concept of sustainable development can be thought of as the EU storyline making possible a political coalition. One might be tempted to argue that sustainable development works well as an umbrella concept uniting disparate constituencies under a common rubric and enabling them to work out how address the environmental future. There is much to be said for this: but ultimately it might just fall apart when the logical contradictions become sharply apparent and where different interests and power 
structures diverge sharply. But just because we share a rhetorical umbrella it does not follow that our interests are common - although for a time it keeps out the rain.

\section{Conclusion}

The incorporation of sustainable development in the EU is clearly of symbolic importance; it can also be argued that it also provides an environmental criterion for the appraisal of development in EU policy. However, there are grounds for caution and possibly scepticism. In the foregoing the issue has largely been pursued conceptually: if this is not sufficiently persuasive, let us ask three indicative questions.

First: why in The 2005 review of the EU Sustainable Development Strategy: Initial Stocktaking and Future Orientation is there a commitment to "making sure that market prices reflect the true costs of economic activities to society" (COM 2005a: 11), but nothing on the environment? One could argue that environmental costs are internalised into social costs - but to do so immediately concedes the point that (whatever the rhetoric) the EU's conception of sustainable development is at bottom narrowly anthropocentric and its rhetoric therefore misleading. Secondly, we find (in the passage on land use and transport) that the EU "is encouraging a shift from road transport to modes with lower environmental impacts, such as clean buses, shipping and rail. The Commission has also proposed that member states introduce infrastructure charging to influence transport demand, by moving towards a situation where prices paid by transport users reflect the full costs to society" (ibid). The question is simple: why is there no mention of air transport? The answer might simply be that this passage is about land use and transport, not air travel. But if that is the answer, the twofold response has to be made that, given the issues discussed raised in the passage, including $\mathrm{CO}_{2}$ emissions and EU targets on climate change, air transport clearly ought to be included; and, further, if it is not included here, where is it to be included? Why does it not appear anywhere in the document? Indeed, it does not appear in this or any of the other EU documents examined above. The passing reference in COM, 2001: "The Commission will propose in 2002 a framework for transport charges to ensure that by 2005, prices for different modes of transport, including air, reflect their costs to society" is only an apparent contradiction, because it refers only to societal costs, not environmental costs. In fact, therefore, it simply adds weight to the claim that the EU conception of sustainability reduces to the weak anthropocentric conception favoured by Beckerman and despised by Richardson. The third question is why does COM 2005a speak of "balanced economic growth and price stability, a highly competitive social market economy, aiming at full employment and social progress, and a high level of protection and improvement of the quality of the environment" (COM, 2005a: 3)? The key word is "balance". The idea of "balance' implies (among other things) commensurability? But that is one of the key points at issue. Whether (and 
how) the elements of a policy on sustainable development are commensurable is a question that points directly to the internal contradictions indicated above.

We are entitled (within the limits of disciplinary appropriateness discussed above) to expect that key concepts at the heart of the policy-making process of the European Union should not be vitiated by inconsistencies, contradictions and the occasional attempt to reconcile them by papering over the cracks. This is especially so where concepts are intended - at least in principle - to be operationalisable and implementable. To some extent the differences in formulation can be traced to their different points of origin in European Council conclusions, thematic strategies expressed in Environmental Action Programmes, and specific legislation. Nonetheless, if policies are to have "sustainable development as their core concern" (COM 2001a: 6) simultaneously with a "reinvigorated agenda for growth and jobs under the revised Lisbon Strategy" (COM, 2006: 2); if "the Commission is firmly committed to sustainable development and wants to set a positive agenda for change" but is also seeking "growth and more jobs, a cleaner and healthier environment" (COM, 2005a: 6), the question has to be posed: how are these incompatible aims to be achieved? The EU's answer is that "our future prosperity and quality of life will depend on our capacity and commitment to change our production and consumption patterns and to decouple economic growth from environmental degradation" (ibid: 6). This is no answer. It is merely ecological modernisation coupled with an understanding of sustainable development which does not even attempt to advance on the Brundtland definition so heavily relied on in EU documentation. The reality is that the EU faces the possibility that its commitment to sustainable development risks implosion as its internal contradictions come to the fore. The 2005 review of the EU Sustainable Development Strategy: Initial Stocktaking and Future Orientation remarks that: "the EU's ability to reflect its global commitments in all its policies is crucial if it is to turn words into deeds, maintaining its credibility as a world leader in the field of sustainable development" (COM, 2005a: 6). Agreed: its credibility is indeed at stake, and will remains so until it attempts seriously to address the contradictions at the heart of its conception of sustainable development. ${ }^{1}$

\footnotetext{
${ }^{1}$ I would like to thank Rudi Wurzel for comments and criticisms on an earlier version 'The European Union and Sustainable Development', CEUS Research Working Paper 1/2007, and Rana İzi for suggestions for revision.
} 


\section{References:}

Baker, S. (1997). 'The Evolution of EU Environmental Policy'. in Baker et al, The Politics of Sustainable Development, London: Routledge

(2007). 'Sustainable development as symbolic commitment: Declaratory politics and the seductive appeal of ecological modernisation in the European Union'. Environmental Politics, 16: 2, 297-317.

Beckerman, W. and Pasek, J. (2001). Justice, Posterity and the Environment. Oxford: Oxford University Press

Collingwood, R.G. 2005 [1933] An Essay on Philosophical Method. second edition, J. Connelly and G. D'Oro (eds) Oxford University Press.

COM (1992). (92) 23, final. Towards Sustainability: A European Community Programme of Policy and Action in Relation to the Environment (1992-2000) (Brussels: CEC, COM).

- (1994). (94) 465, final. Economic Growth and the Environment: Some Implications for Policy Making.

(2001a). 0031, final. The Sixth Environment Action Programme of the European Community: Environment 2010: Our Future, Our Choice'.

- (2001b). 264, final, Communication from the Commission. A Sustainable Europe for a Better World: A European Union Strategy for Sustainable Development. Brussels 15.5.2001.

(2002). 122, final. Commission Report on Environmental Technology for Sustainable Development.

(2005a). 37, final, Communication from the Commission to the Council and the European Parliament. The 2005 review of the EU Sustainable Development Strategy: Initial Stocktaking and Future Orientation. Brussels 9.2.2005.

(2005b). 218, final. Communication from the Commission to the Council and the European Parliament. Draft Declaration on Guiding Principles for Sustainable Development. Brussels, 25.5.2005.

(2005c). 330, final. Communication from the Commission to the Council and the

European Parliament: Common Actions for Growth and Employment: The Community Lisbon Programme.

(2005d). 658, final, Communication from the Commission to the Council and the European Parliament. On the Review of the Sustainable Development Strategy: A Platform for Action. Brussels 13.12.2005.

(2005e). 718, final, Communication from the Commission to the Council and the

European Parliament. On Thematic Strategy on the Urban Environment. Brussels 11.1.2006.

(2006). 211, final, Communication from the Commission to the European Council. A

Citizens’ Agenda: Delivering Results for Europe. Brussels 11.5.2006.

Connolly, W.E. (1983). The Terms of Political Discourse. Oxford: Martin Robertson.

Europe 2020 (2010). Sustainable Growth. Retrieved: 30.11.2011, from 
http://ec.europa.eu/europe2020/priorities/sustainable-growth/index_en.htm

European Council (1988). European Council in Rhodes 2-3 September 1988: Annex on the Environment, Retrieved: 30.11.2011, from http://www.europarl.europa.eu/summits/rhodes/default_en.htm

Euractiv (2005). Sustainable Development: EU Strategy. Retrieved: 30.11.2011, from http://www.euractiv.com/en//sustainable-development-eu-strategy/article-117544

Gallie, W.B. (1964). Philosophy and the Historical Understanding. London: Chatto and Windus.

Hajer, M. (1995). The Politics of Environmental Discourse. Oxford: Oxford University Press.

İzci, R. (2005). 'The Impact of the European Union on Environmental Policy'. in F. Adaman and M. Arsel (eds) Environmentalism in Turkey: Between Democracy and Development? Farnham: Ashgate.

Meadows, D.H., Meadows, D.L., Randers, J. and Behrens, W.W. (1972). The Limits to Growth. London: Pan.

Nietzsche, F. (1968). The Genealogy of Morals (in W. Kaufmann (ed.) Basic Writings of Nietzsche. New York: Modern Library.

Richardson, D. (1997). 'The Politics of Sustainable Development'. in Baker, et al, The Politics of Sustainable Development, London: Routledge: 43-60.

Sartori, G. (1987). The Theory of Democracy Revisited, New Jersey: Chatham House.

World Commission on Environment and Development (WCED) (1987). Our Common Future, Brundtland Report, Oxford: Oxford University Press. 